\title{
WAJAH PANGAN ASIA TIMUR DALAM SELIMUT NEOLIBERALISME STUDI KASUS : CINA
}

\author{
Nur Utaminingsih \\ Universitas Islam Negeri Makassar \\ Email : nur.utaminingsih@uin-alauddin.ac.id
}

\begin{abstract}
The globalizations era, in which every side that involve directly or indirectly always getting encourage even force to build the target, generally, are to be develop country. The $20^{\text {th }}$ century is the era where the actor of international relations was introduced to the new term, some new recipe with the big offers to develop. The recipes that are very influence and became hidden agenda almost happen in every international interactions called neoliberalism.
\end{abstract}

Keywords: Neoliberalism, Food Crisis, Developmentalism

\section{PENDAHULUAN}

\section{EKONOMI POLITIK CHINA}

China adalah suatu negara yang dikenal dengan sejarah sosialisme yang cukup kuat. Hal ini dikarenakan sistem ekonomi dan politik yang dianutnya pada masa lalu adalah sistem yang diambil mengikuti sistem ekonomi politik yang berlaku di Uni Soviet, pusat ideologi kiri pada masa Perang Dingin. Oleh karena itu, China seringkali dianggap sebagai pihak yang bersebelahan dengan aktor-aktor dari wilayah Barat dalam interaksi Global.

Namun, seiring dengan perkembangan zaman dan desakan kebutuhan baik domestik maupun luar negeri, China mengubah sistem ekonomi politik yang selama ini dipegang teguh oleh pemimpin-pemimpin terdahulunya. China sangat dikenal baik dengan kekuatan dinasti-dinastinya. Maksudnya, kekuatan paham yang dianut oleh pemimpin yang tengah berkuasa sangat berpengaruh besar pada umat dan sistem yang berlaku di wilayah tersebut. Begitu pun yang terjadi dalam sistem ekonomi politik China kini.

Kebangkitan ekonomi politik China berawal pada tahun 1970-an. Pada saat itu, China dipimpin oleh pemimpin baru Deng Xiaoping yang membawa beberapa agenda pembaharuan untuk pembangunan China (Kompas, 2006: 13). Dalam bidang ekonomi, Deng Xiaoping mencanangkan Reformasi Ekonomi yang apik dengan tahap-tahap yang jelas dan sistematis pada tahun 1978. Selain itu, dalam bidang politik, Deng Xiaoping pun mencanangkan sistem politik pintu terbuka dalam permainan politik baik domestik maupun luar negeri. 
Saat ini, China tidak mengenal lagi siapa lawan dan kawan dalam berinteraksi, terkhusus interaksi dalam bidang ekonomi yang bersifat global. Karena tersadar akan kebutuhan di era Globalisasi yang semakin beragam dan sulit diraih, Pragmatisme dengan 'hampir' menghalalkan segala cara untuk profit yang memuaskan seakan menjadi langkah utama bagi China.

Reformasi ekonomi yang dicetuskan oleh Deng Xiaoping pada tahun 1978 ditargetkan untuk bermuara pada pembentukan Zona Ekonomi Khusus (Special Economic Zones - SEZs). Adapun wilayah-wilayah yang ditargetkan akan menjadi bagian dari SEZs adalah Shenzhen, Zhuhai, Shantou, Xiamen. Wilayah-wilayah ini lah yang akan menjadi pembuka pertumbuhan ekonomi di China dan selanjutnya memegang peranan yang cukup vital dalam sistem ekonomi dan politik yang berkembang.

Prinsip dasar "Berjalan di Atas Kaki Sendiri” (zou ziji de lu), yang selanjutnya dikembangkan menjadi konsep "Sosialisme dengan Karakteristik China" (zhongguo te se de shihui zhuyi), adalah rencana program pembangunan yang dimotori Deng Xiaoping. Prinsip ini yang kemudian dikenal sebagai model "Sosialisme Ekonomi Baru ala China". Terdapat 9 pokok pikiran yang mencerminkan cita-cita China dengan menyesuaikan Marxisme - Leninisme dengan kondisi nyata di China (Muas, 2008: 324), antara lain:

1. Dalam pencapaian Sosialime; mengambil jalan sendiri.

2. Dalam tahap pencapaian Sosialisme; China di tahap awal Sosialisme.

3. Tugas dasar Sosialisme; membebaskan dan mengembangkan tenaga produksi.

4. Dalam hal gerakan; reformasi dan pengembangan adalah juga revolusi.

5. Dalam kaitan dengan dunia; targetnya dalah perdamaian dan kemajuan, China harus memanfaatkan suasana damai untuk membangun dirinya.

6. Dalam pembangunan politik; berlandaskan 4 prinsip dasar (si ge yuanci) ${ }^{1}$.

7. Mengajukan strategi Tiga Tahap Pencapaian Sosialisme dalam Model Pembangunan Ekonomi Sosialis Baru ala China yang direncanakan Deng Xiaoping.

8. Partai Komunis China (PKC) adalah kepemimpinan utama dengan basis kekuatan kaum pekerja, petani, intelektual dan suku-suku di berbagai wilayah China.

\footnotetext{
${ }^{1}$ Si Ge Yuanci maksudnya: (1) RRC tetap Negara Sosialis; (2) Diktator Demokrasi Rakyat; (3) Keunggulan PKC (Partai Komunis China); (4) Maoisme tetap merupakan ideologi negara, diterima sebagai pegangan partai dan negara.
} 
9. Untuk tetap mempersatukan China, diterapkan model "Satu Negara Dua Sistem" (yi guo liang ce).

Untuk menyukseskan pembangunan yang direncanakannya, Deng Xiaoping telah mengenalkan konsep modernisasi bagi China. Secara jelas, modernisasi ini dijadikan suatu strategi yang utama dalam tiga tahap yang mulai diberlakukan pada tahun 1970-an. Pertama, dengan modernisasi yang diberlakukan di China, GDP harus ditingkatkan menjadi dua kali lipat pada tahun 1980. Tahap ini diharapkan dapat mengeluarkan masyarakat China dalam jurang kemiskinan yang membelitnya selama ini. Kedua, keuntungan ekonomi China harus ditingkatkan hingga empat kali lipat pada tahun 2020. Tahap ini direncanakan sebagai tahap lanjutan bahwa selain masyarakat China lepas dari jurang kemiskinan, juga sebagai jalan untuk memberi kesejahteran bagi seluruh masyarakat. Ketiga, sebagai tahap akhir, ditargetkan pada pertengahan abad ke- 21, modernisasi diharapkan dapat membawa China menjadi negara medium-developped yang sejahtera dan demokratis.

Proses reformasi ekonomi pun dibagi menjadi beberapa tahap pembangunan dan pengembangan. Tahap I (1978-1984), adalah tahap permulaan sekaligus penerapan secara parsial prinsip-prinsip ekonomi pasar dengan penekanan pada wilayah pendesaan. Tahap II (1984-1992), adalah tahap eksplorasi penuh sistem ekonomi pasar dengan penekanan pada wilayah perkotaan. Pada tahap ini, eksplorasi penuh tersebut diimplementasikan pada kebijakan desentralisasi di beberapa wilayah khusus untuk mengembangkan wilayahya sendiri dimana pihak pemerintah pusat hanya bertindak sebagai pengawas. Selain pemerintah daerah yang diberi wewenang dalam proses desentralisasi, perusahaanperusahaan swasta pun diberi keleluasaan untuk mengurus dirinya sendiri dengan tetap bertujuan untuk memajukan pertumbuhan ekonomi China itu sendiri.

Tahap III (sejak 1992), tahap ini dimulai ketika China dengan tegas menyatakan bahwa target reformasi dalah untuk membangun sistem ekonomi pasar sosialis yang baru. Dalam tahap ini, China mengenalkan sekaligus menerapkan sistem ekonomi baru yang dirumuskannya sendiri dan dianggap menguntungkan bagi pertumbuhan ekonominya. Sistem ekonomi pasar sosialis yang baru ini dikenalkan China melalui reformasi 'market oriented' diberbagai bidang yang menjanjikan. Tahap IV ( sejak 2003), pada saat ini, CPC (komisi sentral kongres) membuat keputusan untuk "Penyempurnaan Sistem Ekonomi Pasar Sosialis”. Penyempurnaan ini direncanakan akan diraih di tahun 2020. Adapun pilar 
kesempurnaan pasar sosialis yang dimaksud, yaitu: (1) dititikberatkan pada wilayah kota dan desa secara bersama, (2) pembangunan wilayah lokal, (3) pembangunan sektor sosial ekonomi, (4) adanya keseimbangan pembangunan antara manusia dan alam, dan yang terakhir, (5) peningkatan pembangunan internal dan kerja sama internasional.

Setelah adanya kebijakan reformasi ekonomi China sistem politik pun disibukkan dengan agenda 'buka diri'. Untuk sistem buka diri ini, China mengaturnya kembali dalam tiga tahap yang teratur, diantaranya:

\section{Tahap I - percobaan sistem terbuka diri di SEZs (Special Economic Zones)}

Seperti yang telah penulis tuliskan sebelumnya, SEZs (special Economic Zones) adalah beberapa wilayah pinggiran yang telah ditetapkan pemerintah China sebagai wilayah yang diberikan kebijakan politik khusus dalam bidang ekonomi. SEZs ini adalah pintu bagi China untuk kebangkitan ekonominya, dan pada tahapan lanjutan akan memegang peranan yang cukup vital dalam perkembangan dan pembangunan ekonomi politik di China. Pada tahun 1979, China mencanangkan empat wilayah SEZs dibagian tenggara yang berbatasan dengan Hongkong, Macau, dan Taiwan. Keempat wilayah SEZs ini diberikan kewenangan administratif dalam proses pelaksanaan sistem ekonomi politiknya. Selain itu, wilayah ini pun diberikan keuntungan berupa insentif bagi para investor yang berperan dalam FDI di sistem perekonomian wilayah SEZs ini. Oleh karena diterapkannya kebijakan yang khusus di wilayah-wilayah Zona Ekonomi Khusus ini dan juga kebijakan tersebut bersifat memudahkan, banyak investor tertarik dan turut berinvestasi dalam perekonomian SEZs.

Selama 20 tahun pertama, GDP tahunan SEZs tercatat mencapai 20\%. Pada tahun 2005 saja, FDI SEZs mencapai 1/10. Selain itu, total ekspornya pun mencapai $1 / 5$ dari keseluruhan GDP ekspor China. Hal ini adalah suatu hasil yang cukup mengagumkan, mengingat jumlah penduduk di wilyah SEZs hanya $1 \%$ dari jumlah keseluruhan penduduk China yang pada saat itu tercatat sekitar 1,3 miliar, tetapi bisa menghasilkan keuntungan dan peranan yang besar dalam sistem ekonomi dan politik.

2. Tahap II - membuka diri sepenuhnya

Dari yang mengagumkan yang diraih SEZs, China pun melebarkan kebijakan 'buka diri' nya ke seluruh kota-kota pelabuhan sekitar tahun 1980-an. Selain itu, sebagai perkembangan dari SEZs, China pun mencanangkan lagi 14 Zona Pembangunan Ekonomi dan Teknologi (Economic and Technology Development Zones - ETDZs). Di ke-14 zona ini, kebijakan-kebijakan khusus yang diterapkan sebelumnyadi SEZs juga 
diterapkan disini. Namun bedanya,di ke-14 zona ini lebih ditekankan pada pembangunan dan pengembangan bidang ekonomi dan teknologi. ETDZs ini didirikan di sepanjang Sungai Yangtse.

Saat ini pun dimulai diberlakukannya sistem buka diri yang lebih menyeluruh terkhusus dalam perdagangan dan perekonomian agar bisa berinteraksi lebih mudah dengan negara-negara tetangga. Seiring berkembangannya pembangunan baik di SEZs dan ETDZs, terjadi disparitas yang cukup mencolok antara wilayah timur dan barat China. Hal ini dikarenakan zona-zona khusus banyak yang terdapat di wilayah timur China, karena dekat dengan pelabuhan yang merupakan pintu masuk dan keluar perdagangan dan perekonomian antar-negara. Oleh karena itu, karena disparitas ini, pemerintah China pun mulai menaruh perhatian yang cukup besar ke wilayah barat yang dari segi geografis memang agak terisolasi.

\section{Tahap III - WTO (World Trade Organization)}

WTO adalah satu-satunya lembaga internasional yang mengatur masalah perdagangan antarbangsa dan negara. Inti dari kegiatan WTO adalah adanya persetujuan, negosiasi, dan kesepakatan antarbangsa yang jika disetujui, maka akan diratifikasi dalam parlemennya. Tujuan dari lembaga ini sendiri adalah untuk menolong para produsen baik barang dan jasa, eksportir, dan importir, dalam melaksanakan perdagangan di era pasar bebas sekarang ini. Pada tahun 2001, China telah positif masuk dalam anggota WTO. Dengan kata lain, perekonomian China telah sepenuhnya terintegrasi dalam perekonomian dunia. Ditahun-tahun berikutnya, akan lebih banyak lagi sektor-sektor perekonomian China yang dibuka untuk investor asing dan akan lebih banyak lagi perusahaan-perusahaan China yang akan Go Public dan bersaing dalam pasar bebas.

Sistem Ekonomi Politik China adalah sebuah wajah baru dalam sistem ekonomi politik global. Kesadaran akan keterbelakangan dalam berbagai bidang yang disebabkan oleh praktik menutup diri sehingga tidak mengikuti perkembangan zaman dijadikan alasan yang tepat untuk memulai strategi 'buka diri' China. Masuknya investasi asing dan peranan perdagangan internasional di tahun 1980-an pada perekonomian China menyebabkan tumbuhnya industri-industri di wilayah perkotaan (Eckaus, 1997: 67).

Belajar dari pengalaman-pengalaman bangsa lain yang sukses dengan pembangunan neoliberal, lalu menyerapnya dengan menyesuaikan kebutuhan negara adalah resep utama China. Dirumuskannya Sistem Ekonomi Politik Pasar Sosialis yang baru, dengan Sistem 
Politik Terbuka adalah pasangan yang cocok dalam pembangunan China. Kolaborasi inilah yang kemudian mengantar China dalam posisinya kini di era Globalisasi. Kekuatan China dengan tetap memegang teguh karakter bangsanya tetap dipegang dan dipertahankan untuk menjaga posisi dan powernya. Karena itu, sistem ekonomi politik China terkenal kuat dan tidak gampang terpengaruh oleh hingar bingar ekonomi politik global yang tengah goyah akhir-akhir ini.

\section{KERANGKA ANALISIS}

\section{GURITA NEOLIBERALISME}

Perdamaian adalah tujuan utama dalam dunia internasional. Dalam setiap interaksi global, hal ini seringkali menjadi latar belakang setiap gerak aktor dunia. Dalam Ilmu Hubungan Internasional, terdapat banyak sekali paradigma yang dapat dijadikan kacamata dalam menganalisis fenomena-fenomena global yang kemudian berpengaruh pada sistem internasional. Adapun fenomena global yang utama dan dapat dilihat dalam berbagai paradigma Ilmu Hubungan Internasional adalah perdamaian.

Perdamaian, seiring dengan bergulirnya zaman dan keadaan, pun telah memiliki makna yang beragam. Pada masa Perang Dunia (1914-1919), saat dimana peperangan adalah hal yang lumrah dalam interaksi internasional, perdamaian seringkali dianggap adalah suatu situasi dan kondisi tanpa perang, dimana setiap masyarakat dapat hidup aman dalam negara masing-masing. Mimpi akan perdamaian inilah yang kemudian memicu terjadinya negosiasi antar-aktor internasional untuk menghentikan PD tersebut. Sampai pada akhirnya disepakati dibentuknya LBB (Liga Bangsa-Bangsa) sebagai forum bersama setiap negara dalam dunia internasional untuk tetap menjaga semangat perdamaian. Namun, hal ini ternyata tidak berlangsung lama. Meledaknya Perang Dunia II (1939-1945) di tiga benua besar, yakni Asia, Afrika, dan Eropa, seakan menjadi jawaban bahwa keinginan untuk saling menguasai dan menjadi pemimpin bagi yang lain masih sangat besar. Fokus dunia masih pada kekuatan militer dan bagaimana bertahan dalam ketegangan kekerasan fisik.

Sampai pada abad ke-20, pasca Perang Dunia II, dunia internasional dihadapkan lagi pada suatu persaingan terselubung yang dikenal dengan istilah Perang Dingin. Tidak pernah jelas kapan awal dan akhirnya, yang jelas, pada saat ini yang terjadi adalah adanya persaingan ideologi antara Blok Barat yang berpaham liberal dan Blok Timur dengan pahaman sosialis-komunisnya. Masing-masing aktor memiliki solusi masing-masing untuk menjaga perdamaian dunia yang sudah menjadi target utama. Yang menjadi masalah, 
setiap pihak merasa solusinya adalah yang terbaik, dan senantiasa menutup diri serta menganggap solusi dari pihak lain adalah hal yang mendesak dan merugikan. Persaingan yang tadinya berawal dari bidang militer kemudian berlanjut pada bidang sosial, ekonomi dan politik.

Pendapat baru mengenai perdamaian global pun mulai merebak. Pada masa ini, perdamaian dianggap suatu keadaan dimana setiap individu merasa aman akan kebutuhan hidupnya. Perdamaian sangat dekat dengan kesejahteraan masyarakat. Diyakini, bahwa apabila kesejahteraan individu telah tercapai, maka perdamaian pun secara tidak langsung akan terwujud. Hal ini dikarenakan, setiap pihak merasa tenang dan tenteram akan hidupnya yang sejahtera.

Pecahnya Uni Soviet menjadi beberapa bagian seperti memberi gambaran tersurat akan kelemahan sistem yang selama ini dipegangnya. Hal ini menjadi awal dan mengantar populernya paham liberal yang dibawa dari Blok Barat. Sistem ekonomi kapitalis dan sistem politik demokrasi pun seakan menjadi solusi bagi negara-negara baru dan negara lama yang memiliki agenda untuk memajukan kesejahteraan rakyatnya. Mulai saat ini lah munculnya paham neoliberalisme dan segala agenda-agendanya yang 'katanya' dan 'semoga' dapat memajukan serta mewujudkan kesejahteraan global.

Mega Savitri, dalam bukunya, "Ekspansi Global Neoliberalisme”, merumuskan ada beberapa pokok pikiran Neoliberalisme yang bisa kita pegang untuk mengenalinya secara lebih dekat. Pokok-pokok pikiran yang dimaksud adalah: Pertama, minimnya campur tangan negara dan otoritas berada di tangan pasar. Kedua, diterapkannya privatisasi dan swastanisasi. Ketiga, penghilangan semua bentuk subsidi pada aset-aset negara dan posisi serta kewenangan pelaku semua diberikan pada pasar. Keempat, diterapkannya liberalisasi pada setiap hal, dimana aturan nasional diminimalisirkan, atau bahkan ditiadakan, dan lebih berorientasi pada pembangunan global. Kelima, mendorong terus pertumbuhan ekonomi, terutama dengan mendorong terus ekspor barang keluar negeri. Keenam, pasar adalah aktor utama yang berfungsi sebagai pengatur dan pengontrol sistem ekonomi. McMichael sendiri, dalam bukunya Development and Social Change; A Global Perspective membahasakan wacana dominan dari Neoliberalisme itu sendiri bisa dilihat dalam bentuk liberalisasi pasar, privatisasi, akses modal dan perdagangan bebas, dan selanjutnya (McMichael, 2012). 


\section{METODE PENELITIAN}

Neoliberalisme senantiasa membawa sistem kapitalis dalam perekonomian dan perdaganganannya. Sistem kapitalis adalah sistem yang berkekuatan pada modal dan berorientasi profit sebesar-besarnya dalam setiap interaksi pasar. Bagi para tokoh kapitalis dan neoliberal, sistem ini dianggap sebagai jawaban akan kebutuhan masyarakat dunia pasca era kolonialisme khususnya di Negara-Negara Berkembang. John Locke, seorang filsuf abad ke-18, menganggap orang-orang pra-kapitalis adalah orang-orang yang bersifat feodal terhadap penduduknya. Selain itu, penduduknya pun senantiasa menjadi objek yang selalu ditindas oleh pemimpin yang tengah berkuasa. Kaum liberal dan neoliberal digolongkan olehnya adalah orang-orang yang punya hak hidup, merdeka dan sejahtera.

Hal-hal positif inilah yang senantiasa dibawa oleh para neolib untuk memasyarakatkan Neoliberalisme di seluruh dunia, terkhusus Negara-Negara Berkembang dalam agenda Developmentalisme, Demokratisasi, Pasar Bebas dan Globalisasi. Sistem kapitalisme dianggap membawa semangat yang dinamis, senantiasa memberi kesempatan bagi setiap individu, dan kompetisi antar-aktor. Namun, dalam prosesnya ketiga poin tersebut, senantiasa ada kepentingan pribadi dan keuntungan individu yang selalu 'diusahakan' oleh setiap aktor yang berinteraksi. Sehingga, menghalalkan segala cara untuk kedua target terselubung itu seringkali dilakukan. Dan secara tidak langsung, sistem ini justru menumbuhkan egoisme antar-aktor dan individualitas yang tinggi diantara mereka.

Neoliberalisme adalah pandangan yang tetap memandang konflik. Perang dan damai adalah topik yang masih sering dibicarakan. Namun, konflik yang dibahas dalam Neoliberalisme tidak lagi mengedepankan isu security sebagai pusat analisis. Pusat analisisnya kini adalah kesejahteraan, modernisasi, lingkungan dan lain-lain. Neoliberal, yang kini senantiasa menjadi solusi pembangunan bagi Negara-Negara berkembang, selalu mendukung SAP (Structural Adjustment Program) dari IMF dan Bank Dunia, yang kemudian dijadikan resep untuk membangun negara (Strange, 2002: 23). Adapun poinpoin khusus yang dibawa yang dibawa dalam SAP, yaitu pertama, Negara yang bersangkutan disarankan atau bahkan 'diwajibkan' untuk mengekspor sumber daya alam dengan mudah dan murah, agar proses perdagangannya berjalan lancar, sehingga dimudahkan mendapat sumber dana untuk membayar utang. Dan kedua, Negara Berkembang diminta mengurangi, bahkan menghentikan, subsidi BUMN negaranya, terkhusus dalam bidang pendidikan dan kesehatan. 


\section{PEMBAHASAN}

\section{SISTEM PANGAN - NEOLIBERALISME - CHINA}

Fenomena Krisis Pangan dapat dipahami dalam dua kondisi besar. Pertama, Krisis Pangan adalah suatu keadaan dimana harga pangan melambung tinggi dan berakibat pada susahnya masyarakat mendapat akses untuk menikmati pangan tersebut. Kedua, Krisis Pangan juga bisa dikatakan sebagai suatu keadaan dimana stok pangan sudah menipis dan tidak bisa memenuhi kebutuhan pangan masyarakat yang melimpah. Krisis Pangan merupakan dampak dari kebijakan neoliberal yang mengusik kemandirian pangan lokal setiap wilayah menjadi bentuk ketergantungan kelompok Selatan terhadap liberalisasi perdagangan pangan (McMichael, 2012: 242).

China selama ini dikenal sebagai negara yang cukup berhasil dalam kebangkitan ekonomi dan pembangunan negara di era Globalisasi. Dengan langkah pragmatis dalam sistem ekonomi politik yang ditempuhnya, China bisa dikatakan berhasil mengkolaborasikan sistem ekonomi kapitalis dengan kultur asli nya dalam resep Sistem Ekonomi Politik Sosialisme wajah baru. Jika dianalisis lebih lanjut, wajah sistem ini sebenarnya tidak lebih jauh dari Neoliberalisme.

Tahun 2010-2011 adalah masa-masa mendebarkan bagi negara-negara di Amerika dan Eropa. Krisis ekonomi di berbagai negara dikawasan tersebut seakan membayangi setiap interaksi ekonomi dan politik. Selain itu, proses demokratisasi di wilayah Timur Tengah pun masih saja meramaikan media-media internasional. Di sisi lain dunia, benua Afrika, masih disibukkan dengan agenda keterbelakangan, kelaparan, dan kemiskinan yang seperti perangkap bagi mereka untuk keluar. Walaupun banyak sekali bantuan-bantuan luar negeri baik berupa hibah, maupun utang yang sudah dikerahkan sebagai penyelamat, entah dalam arti sebenarnya atau terselubung. Asia dengan kebangkitan-kebangkitan ekonomi yang menanjak, terkhusus di belahan timur Asia, dianggap sebagai kekuatan baru dalam dunia ekonomi politik internasional. Adapun negara yang katanya diramalkan akan menjadi salah satu kekuatan baru dalam sistem internasional, yaitu China.

Dibalik segala kesuksesan China dalam agenda pembangunan dan kebangkitan sistem ekonomi politik global, ternyata fenomena Krisis Pangan tidak menjadi pengecualian bagi negara ini. Pada tahun 1958-1961, tercatat bahwa terjadi Krisis Pangan yang hebat dan kelaparan di China. Pada saat ini, Mao Zedong memiliki mimpi untuk membangun China menjadi salah satu negara industri di dunia terkhusus dalam bidang 
logam. Cita-citanya, dalam waktu dekat, kedudukan China bisa mendekati bahkan sejajar dengan Inggris dalam produksi logam dunia. Untuk mencapai target tersebut, warga China ditekan untuk bekerja diluar batas wajar agar memberi hasil lebih dalam industri logam. Dampaknya, sistem pertanian pun menjadi terbengkalai karena kurangnya perhatian pemerintah. Hasil produksi tidak maksimal dan berdampak pada tidak terpenuhinya kebutuhan pangan dalam negeri. Selama tiga tahun itu, jumlah kematian mencapai 14-26 juta orang.

Setelah itu, muncullah Deng Xiaoping dengan agenda reformasi ekonomi nya dan resep Sistem Ekonomi Pasar Sosialis Baru-nya. Dengan sistem ini, dilaksanakan beberapa tahap perbaikan dan pembangunan untuk memperbaiki hal-hal negatif yang telah dilewati China sebelumnya dan menata baik hal-hal yang akan dilalui China dimasa yang akan datang. Perlu diakui betapa rapi nya tahap-tahap yang dirumuskan pemerintah China dibawah kepemimpinan Deng Xiaoping dengan menguatkan pondasi awal pada pertumbuhan masyarakat pendesaan dan bidang pertanian, kemudian bangkit sebagai negara industri. Namun, ternyata kenyamanan dalam kebangkitan ekonomi dan keuntungan yang cukup besar dalam bidang industri seakan membuat China lupa dan kembali tidak bisa bergerak dikala Krisis Pangan kembali merebak pada tahun 2008 dan 2011 kini.

Keputusan untuk masuk dalam sistem ekonomi politik Neoliberal jelas memiliki konsekuensi tersendiri bagi China. Adanya ketergantungan satu sama lain adalah hal yang tidak bisa dihindari. Meski tergolong negara yang cukup kuat dan terhindar dalam krisis ekonomi global yang telah menggerogoti sebagian wilayah Eropa dan Amerika, ternyata China belum bisa bebas dari fenomena Krisis Pangan dewasa ini.

Di awal tahun 2011, FAO (Food and Agriculture Organization) telah membunyikan lonceng peringatan bagi negara-negara dunia akan naiknya indeks-indeks harga pangan melebihi harga yang telah menjadi rekor tertinggi di tahun 2008 lalu. Selain itu, Robert Zoellick, presiden Bank Dunia pun menyatakan ada beberapa negara dikawasan Asia yang cukup berada di posisi yang mengkhawatirkan akan fenomena ini, yaitu India, Indonesia, dan China. Tiga negara ini tergolong negara yang cukup rawan dikarenakan jumlah penduduknya yang banyak dan kesuksesan ekonomi yang tengah diraihnya.

Masalah populasi penduduk memang seringkali dijadikan penyebab utama fenomena Krisis Pangan di berbagai belahan dunia, tergolong China. Menurut data Biro Statistik Nasional China (NBS), dicatat sensus terakhir pada 2011, populasi penduduk 
China menempati urutan pertama dengan jumlah penduduk 1.354 milyar jiwa (Kompas, 2013). Sistem satu anak yang dicanangkan pemerintah China ternyata masih mengantar China pada posisi teratas dalam statistik jumlah penduduk dunia.

Data tersebut di atas kemudian sangat mendukung fenomena Krisis Pangan yang tengah terjadi di China. Selain itu, maraknya kebijakan larangan ekspor pangan dari beberapa negara produsen pangan yang juga tengah kekurangan produksi semakin menambah penderitaan China dalam permasalahan sistem pangannya. Satu hal yang unik di China, selain jumlah penduduk, kesuksesan ekonomi yang tengah dinikmati China juga menjadi salah satu penyebab Krisis Pangan di negara ini.

Kebangkitan ekonomi, jelas berdampak positif pada pengusaha-pengusaha yang sukses di pasar dalam sistem perekonomian China ini. Modernisasi, demokratisasi dan sistem buka pintu yang dicanangkan pemerintahan China secara tidak langsung sebenarnya telah membawa semangat kapitalisme dan neoliberalisme. Setiap tindakan akan dikiblatkan dan difokuskan untuk meraih profit setinggi-tingginya. Modal akan memegang peranan yang besar dalam sistem ekonomi politik baik global dan domestik. Namun, realitanya, tidak setiap aktor dapat menikmati posisi puncak selamanya. Semangat persaingan yang dibawa oleh Sistem Ekonomi Sosialis Wajah Baru (baca: Sistem Kapitalis ala China) jelas memberi posisi akan adanya pihak yang menang dan kalah.

Tindakan yang berorientasi pada profit yang besar di segala aspek sangat dekat dengan keserakahan. Profit yang besar dalam waktu yang singkat adalah impian setiap pihak dalam sistem ini. Proses industrialisasi pun menjadi metode utama dalam mewujudkan cita-cita tersebut. Hal inilah yang seringkali menempatkan aspek pangan dan pertanian menjadi fokus yang kesekian dalam sistem ekonomi politik suatu negara. Karena bidang ini menghasilkan sangat sedikit keuntungan dalam waktu yang cukup lama. Namun, jika profit yang besar itu telah diraih oleh pihak yang bersangkutan, dan sistem pangan kurang mendapat perhatian yang lebih, jelas berdampak negatif pula.

Standar hidup masyarakat China telah meningkat seiring dengan kebangkitan ekonomi yang tengah diraihnya. Hal ini kemudian berbanding lurus pada peningkatan konsumsi masyarakat China. Namun, fenomena ini tidak didukung oleh sistem pangan yang bisa memenuhi kebutuhan masyarakat. Sehingga pangan menjadi suatu hal yang langka. Dalam sistem perdagangan pangan, dikala permintaan pasar lebih tinggi daripada penawaran, indeks harga pun akan naik. Untuk para pengusaha yang turut sukses seiring 
dengan kebangkitan ekonomi China, hal ini mungkin tidak terlalu dipermasalahkan. Namun, bagaimana dengan para warga dari kelas biasa yang masih terjebak dalam ketidakadilan ekonomi dan kesenjangan sosial di China?

Presiden China (2008-2008), Hu Jintaou mencatat kenaikan indeks harga pangan di China telah mencapai $11,7 \%$ pada November 2010. Di saat presiden China ini tengah menenangkan warganya dengan janji akan membantu kelompok masyarakat yang sangat membutuhkan bantuan dalam menghadapi krisis pangan global, Olivier De Schutter (2010), ahli PBB soal pangan menyatakan China harus memperhatikan lebih besar ancaman Krisis Pangan di negaranya. Degradasi kualitas lahan dan banyaknya lahan yang dialihfungsikan dari pertanian menjadi industri merupakan penyebab utama bagi ancaman pangan di China. Menurut PBB, saat ini saja harga pangan telah naik rata-rata sekitar $83 \%$ per tahun. Bahkan, untuk harga gandum saja telah naik meroket hingga 181\%. Jika tidak diantisipasi lebih dini dan maksimal, hal ini pun akan berpengaruh pada kondisi pangan global.

Hal lain yang cukup berpengaruh dalam ancaman sistem pangan Asia Timur, terkhusus China, adalah meningkatnya volume kehidupan perkotaan. Selain berkurangnya jumlah lahan yang dialihfungsikan menjadi kebutuhan-kebutuhan industri modern, sistem pengairan yang merupakan kebutuhan utama pertanian di China juga mulai dialokasikan untuk memenuhi kehidupan hidup masyarakat perkotaan. Karena tidak maksimalnya sistem irigasi lahan, hasil pertanian pun semakin menurun baik dari segi kuantitas, maupun kualitasnya untuk menjawab kebutuhan pangan masyarakat.

Masalah lain yang tidak kalah penting adalah produktivitas pangan yang tidak mengalami kenaikan yang signifikan. Penemuan teknologi dalam pembenihan belum muncul sejak beberapa tahun yang lalu. Jepang masih saja bersandar pada benih padi yang ditemukan sejak 1998. China dan Korea Selatan pada 2012 baru akan menghasilkan padi dengan produktivitas yang mendekati produktivitas padi jepang. Di Eropa, hal yang sama juga terjadi di inggris, jerman, dan perancis masih belum bisa meningkatkan produktivitas gandumnya.

Data lainnya menyebutkan, di China, pada awal tahun 2011, tercatat bahwa penjualan mobil dalam satu tahun terakhir mencapai 20 juta kendaraan. Dalam hitungan kasar saja, di AS, setiap penjualan 5 juta kendaraan membutuhkan lahan hampir setengah juta hektar. Bisa dibayanglan berapa juta hektar lagi lahan produktif yang dialihfungsikan untuk kebutuhan euphoria dan bersifat sekunder seperti ini di China. 
Di tahun 1990-an, salah seorang penulis, Brown, dalam bukunya "Who Will Feed China?" sempat membangkitkan ketersinggungan pemerintah China. Namun, saat ini, Brown telah diangkat menjadi salah satu penasehat China dalam menghadapi fenomena krisis pangan di negara tersebut . akademisi Ilmu-Ilmu Sosial di China bahkan memberinya gelar sebagai salah satu anggota kehormatan.

Groundwater tables di China yang merupakan produsen beras terbesar dunia saat ini terus saja mengering. Gletser di Himalaya pun mengering dan menghilang lebih cepat dari yang telah diantisipasi sebelumnya. Padahal, gletser tersebut adalah sumber pengairan utama bagi Sungai Kuning dan Sungai Yangtse selama musim panas. Sungai ini pun berpengaruh cukup besar dalam proses irigasi lahan-lahan pertanian di China. Pemanasan global yang menjadi penyebab beberapa permasalahan alam lainnya adalah sebab yang tidak bisa terelakkan dalam fenomena Krisis Pangan Global.

\section{KESIMPULAN}

Sistem Ekonomi Politik Sosialis Baru (baca: Sistem Kapitalis ala China) memang seringkali dijadikan solusi oleh banyak pihak untuk bertahan dalam sistem ekonomi politik internasional yang sedikit goyang akhir-akhir ini. Kebangkitan ekonomi China yang mendapatkan pengakuan oleh dunia ekonomi politik global seperti sebuah sistem yang diimpikan oleh banyak Negara Berkembang yang tengah dalam proses Pembangunan negaranya. Namun, kebangkitan ini ternyata tidak dapat menggorogoti China dalam wajah yang berbeda. Tingginya inflasi, yang kemudian berdampak pada meroketnya harga pangan global, karena dipengaruhi oleh meningkatnya standar hidup masyarakat China yang tingkat konsumsinya pun tengah meningkat.

\section{DAFTAR PUSTAKA}

China Food Crisis Will Exacerbate Global Shortage . n.d. http://indiatoday.intoday.in/story/China's+food+crisis+will+exacerbate+global+sho rtage/1/9488.html, (accessed November 15, 2011).

Eckaus, Richard. "China" Going Global : Transition from Plan to Market in the World Economoy. New York : Colombia University Press, 1997.

Holsti, R. Ole. "Models of International Relations : Realist and Neoliberal Perspective on concflict and cooperation" The Global Agenda : Issues and Perspective 4th Edition . United State : Mc. Hill, Inc., 1984.

Irfan, Fahmi. Pengantar Politik Ekonom. Bandung: Alfabeta, n.d.

Kompas. Cermin dari Cina Geliat Sang Naga di Era Globalisasi . Jakarta : Buku Kompas, 2006. 
Makassar, Himahi Unhas. "Neoliberalisme : Sebuah Perspektif dan Konsekuensi Praktisnya ." Jurnal Alternativa Vol. 1 Juli - Desember 2009, 2009.

Maryoto, Andreas. Akar Krisis Pangan Dunia . November 13, 2011.

McMichael, Philip. Development and Social Change : A Global Perspective . California : SAGE Publication, 2012.

Muas, Tuty N. "30 tahun Reformasi RRC : Reformasi Gradual yang Penuh Penyusaian" 30 Titik Balik Historiografi di Indonesia". Jakarta : Wedatama Widya Sastra , 2008.

Pettiford, Jill Steans \& Llyod. Hubungan Internasional : Perspektif dan Tema. Yogyakarta : Pustaka Pelajar, 2009.

Primus, Josephus. "Susut, Jumlah Usia Produktif di China . Januari 18, 2013. https://internasional.kompas.com/read/2013/01/18/17203147/Susut..Jumlah.Usia.Pr oduktif.di.China (accessed Juni 5, 2019 ).

Schutter, Olivier De. Food Commodities Speculation and Food Price Crises, Briefing Note - 02 . United Nations , 2010.

The Price of Rice in China - Why This Food Crisis is Different From Last? April 29, 2011. http://indiatoday.intoday.in/story/China's+food+crisis+will+exacerbate+global+sho rtage/1/9488.html, (accessed November 15, 2011).

Winarno, Budi. Melawan Gurita Neoliberalisme. Yogyakarta : Penerbit Erlangga, 2010. 